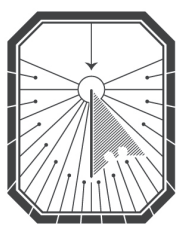

KYIV-MOHYLA

LAW \& POLITICS JOURNAL

KYIV-MOHYLA SCHOLARLY PEER-REVIEWED JOURNALS

Learning the Lessons from the Euromaidan: The ups and downs of LGBT Activism in the Ukrainian Public Sphere

Author(s): Maryna Shevtsova

Source: Kyiv-Mohyla Law and Politics Journal 3 (2017): 157-180

Published by: National University of Kyiv-Mohyla Academy

http://kmlpj.ukma.edu.ua/ 


\title{
Learning the Lessons from the Euromaidan: The ups and downs of LGBT Activism in the Ukrainian Public Sphere
}

\author{
Maryna Shevtsova \\ Institute for Euro-Atlantic Cooperation \\ Humboldt University
}

\begin{abstract}
This paper addresses the growing visibility of LGBT civil society organizations in Ukraine's political sphere after the Euromaidan. Drawing on the data collected through in-depth, semistructured interviews; participant observations; and an analysis of social media, this study answers this question: How did Ukrainian LGBT groups reshape their political strategies after the Euromaidan?

The Euromaidan was an anti-government, citizens' protest that began in November 2013 in response to the government's unlawful actions. During it, Ukrainian LGBT activists strategically decided to keep their presence in the protest camp invisible. Though this helped to avoid conflicts, the LGBT movement's hopes for reforms in sexual minorities' rights after the Euromaidan remained unfulfilled. This article illuminates how the LGBT activists' approach to the public sphere in post-Euromaidan Ukraine has changed. It argues that the LGBT movement's disillusion over the new government's lack of support triggered a wave of LGBT activism that has resulted in new political strategies. Despite the visible backlash against sexual minorities in 2014-2015, Ukraine's current turmoil has given the LGBT movement opportunities for political alliances and transnational activism that have seemed to have borne fruit.
\end{abstract}

Key Words: European Union, Ukraine, civil society organizations, LGBT, Euromaidan.

\section{(7)}

\section{Introduction}

November 2015 was marked by an important development for the Ukrainian LGBT ${ }^{1}$ movement. On November 12th, with 234 votes of 45 , the Ukrainian parliament passed a much-contested amendment to the Ukrainian Labor Code. The amendment protected LGBT individuals against discrimination based on sexual orientation and gender identity. Its adoption was among the

While I have decided to choose here LGBT abbreviation that stands for "lesbians, gay, bisexual, and trans people," it is worth-noting that this is not to claim that LGBT community in Ukraine is a homogenous group. Neither have all four groups been equally represented during the events discussed in this article. This paper abstains, however, from discussing the power structures and complex interactions within Ukrainian LGBT organizations for the sake of brevity and little relevance for the main argument. 
prerequisites for visa-free travel by Ukrainians to the European Schengen area. And for the Ukrainian LGBT movement, it became an important milestone: it was the government's first legal action in support of LGBT rights since the decriminalization of homosexuality in 1991. Moreover, because its adoption resulted from pressure from European Union (EU) institutions and from Ukrainian civil society organizations (CSOs) joining efforts with pro-European members of Ukraine's parliament, it became one of the first examples of the Ukrainian LGBT movement's increasing political participation.

Three years earlier, it would have been impossible to envision this development. In 2012, Ukraine's parliament, following Russia's example, had passed in the first reading a bill banning "propaganda of homosexuality." In 2013, the then Prime Minister of Ukraine, Mykola Azarov, publicly justified the government's reluctance to sign an association agreement with the EU by falsely claiming the EU was pushing Ukraine to legalize same-sex marriages. Yet, by June 2016, after a peaceful Pride Parade in the centre of Kyiv, and supportive statements of Petro Poroshenko, Ukraine's President, regarding the rights of LGBT people, external observers started talking about increased support by Ukrainian authorities for LGBT rights. ${ }^{2}$ What has changed since then?

The anti-government protests in 2013-2014 in the centre of Kyiv referred to as the "Euromaidan" emerged as a mass mobilization of Ukrainians against the state security forces' violent dispersal of a peaceful gathering. The participants protested the decision of then President Yanukovych's government not to sign an association agreement with the EU and potentially to have closer ties with Russia. For the LGBT community in Ukraine, the Euromaidan turned out to be a pivotal moment. Being a part of the Euromaidan from its beginning, the members of LGBT organizations collectively decided to keep their presence in the protest camp invisible. They did this because of regular provocations arranged by some pro-Russian groups. These provocations were based on speculation about European integration prospects for Ukraine and LGBT rights being "imposed" by the West on Ukrainian society against national moral values. This article analyses the changes in the strategies of LGBT CSOs in Ukraine to answer the question how those have been reshaped after the Euromaidan.

To answer this question, the article engages with the interaction modes framework suggested by Holzhacker that explains the development of social movements as a gradual shift from morality politics to incremental change and, finally, to the high-politics mode. ${ }^{3}$ The study draws on the empirical data collected both by desk-work, including document and media analysis, and by field-work consisting of more than 30 semi-structured, in-depth interviews with

$2 \quad$ Inna Shevchenko, "Kyiv Pride 2016: Why are Ukraine's Politicians Silent on Attacks against LGBT People?" International Business Times, June 11, 2016, accessed December 20, 2017, http://www.ibtimes. co.uk/kiev-pride-2016-why-are-ukraines-politicians-silent-attacks-against-lgbt-people-1564830; Matthias Williams and Natalia Zinets, “Praise from West after mostly Peaceful Kyiv Pride March,” Reuters, June 12, 2016, accessed December 21, 2017, http://www.reuters.com/article/us-ukraine-prideparade-idUSKCN oYY oFD.

3 Ronald L. Holzhacker, "National and Transnational Strategies of LGBT Civil Society Organizations in Different Political Environments: Modes of Interaction in Western and Eastern Europe for Equality," Comparative European Politics 10 (2010): 1-25. 
LGBT activists, experts, and policy-makers. The interviews were conducted in Kyiv, Dnipro, and Berlin from 2013 through 2016. The interviews lasted from 30 to go minutes. The questions asked addressed the work of LGBT civil society organizations in Ukraine, the participation of LGBT activists in Euromaidan protests, the assistance of foreign donors (the EU, in particular), LGBT activists' interactions with political actors, and the interviewees' perceptions of attitudes towards LGBT people in Ukraine. The list of the interviews can be found in this article's appendix.

This article argues that the strategy of invisible participation proved effective in preventing conflicts with the right-wing radicals in the protest camp. However, strategy led to the role LGBT activists played in the protests being overlooked and the hopes of the community for the reforms for sexual minorities' rights after the Euromaidan being unfulfilled. These outcomes pushed the Ukrainian LGBT community to reconsider its strategies and to reshape the ways in which it negotiated its external environment. The persistent growth of the Ukrainian LGBT political activism that followed, supported by the incentives coming from the European institutions against a backdrop of a pro-Western government coming to power, resulted in obvious positive changes for LGBT rights in Ukraine.

This article, focusing on the changing interaction modes of Ukrainian LGBT civil society organizations, is structured as follows: First, I introduce the theoretical and conceptual framework used to study political action of LGBT groups in Ukraine. In the next two sections, I focus on the emergence of Ukrainian LGBT civil society organizations and their participation in the Euromaidan protests. I then explain how the mode of interaction of LGBT activist changed with the post-Euromaidan developments and conclude with the discussion of the political opportunities that the political instability in Ukraine in 2015 and 2016 created for LGBT movement.

\section{Studying LGBT Civil Society Activism: Strategies and Interaction Modes}

In this section, I discuss the theoretical and conceptual framework employed in this article as well as the data-collection methods. My choice to make the Ukrainian LGBT movement's strategies the core of this article's argument draws on the substantial body of social movement literature presenting strategies as a way to better understand actors and their intentions ${ }^{4}$ and to grasp the interactions among the intentions of a "variety of deliberate actors." ${ }^{5}$ While social movement scholars pay a great deal of attention to studies of movements' strategies and tactics, ${ }^{6}$ a conceptual agreement concerning the ultimate distinction between "strategy" and "tactic" has

Federiko M. Rossi, “Conceptualizing Strategy Making in a Historical and Collective Perspective,” in Social Movements Dynamics. New Perspectives on Theory and Research from Latin America, ed. Federiko M. Rossi and Marisa von Blow (London and New York: Routledge, 2016), 15. James Jasper, “¿De la estructura a la acción? La teoría de los movimientos socials de spués de los grandes paradigmas," Sociologica 27.75 (2012): 30.

6 Donatella Della Porta and Mario Diani, Social Movements. An Introduction (Oxford, UK: Blackwell Publishing, 2006); Lee A. Smithey, "Social Movement Strategy, Tactics, and Collective Identity, Sociology Compass 3.4 (2009): 658-71; Sidney Tarrow, Power in Movement. Social Movements and Contentious Politics (Cambridge: Cambridge University Press, 1994); Verta Taylor and Nella Van Dyke, "Get up, Stand up": Tactical Repertoires of Social Movements," in The Blackwell Companion to 
not yet been reached. A tactic is defined as an "important routine,"7 "repertoire of action" that is "finite" and "constrained in both time and space" 8 or as "the means and plan to win a single campaign." ${ }^{9}$ A strategy is described as "many types of decisions made in the interest of a social movement" ${ }^{10}$ or as way in which a social movement is reaching its goals. ${ }^{11}$ The choice of a strategy is found to have a strong impact on a group's persistence ${ }^{12}$ and on a movement's identity ${ }^{13}$ since a strategy remains a "fundamental dimension of protest alongside physical resources, culture, and biography." 14 Wishing to avoid conceptual confusion, I refer here to a strategy as the "the conscious decisions and actions activists take to pursue their objectives, including tactical choices" (italics mine). ${ }^{15}$

Holzhacker, in his work on national and transnational strategies of LGBT civil society organizations (CSOs), conceptualizes three so-called "modes of interaction" of organizations with their political environment: morality politics, incremental change, and high-profile politics. ${ }^{16} \mathrm{He}$ argues that these modes define the strategies that a CSO may use to reach its political goals (see table 1). Within the morality politics mode of interaction, a CSO is lacking resources to increase its public visibility so it can only use a (peaceful) LGBT protest or march as a form of public gathering. When a LGBT rights issue is in the sphere of morality politics, it usually means low chances for the LGBT community to build coalitions within existing political structures, as the government often does not support sexual minorities and CSOs dealing with LGBT rights are usually not self-sustaining and depend on external funding from abroad. As is described later in this article, pre-Euromaidan Ukraine presented an exemplary case for the morality politics mode of interaction. When the visibility of the LGBT community increases to the extent that small-scale public events (conferences, Pride Parades, media appearances on national channels) become possible, this often coincides with the community's first alliances with more progressive

Social Movement, ed. David A. Snow, Sarah A. Soule, and Hanspeter Kriesi (Malden, Oxford, Carlton)

Blackwell Publishing Ltd, 2004): 262-93.

James M. Jasper, The Art of Moral Protest: Culture, Biography, and Creativity in Social Movements

(Chicago: University of Chicago Press, 1997): 237.

8 Della Porta and Diani, Social Movements, 181.

9 Sharon Erickson Nepstad and Stellan Vinthagen, "Strategic Choices in Cross-National Movements: A Comparison of the Swedish and British Plowshares Movement," in Strategies for Social Change, ed. Gregory Maney, Rachel Kutz-Flamenbaum, Deana Rohlinger, and Jeff Goodwin (Minneapolis: University of Minnesota Press, 2012): 282. Smithey, "Social Movement Strategy," 66o.

11 Rossi, “Conceptualizing Strategy Making," 15.

12 Bob Edwards and John D. McCarthy, "Strategy Matters: The Contingent Value of Social Capital in the Survival of Local Social Movement Organizations," Social Forces 83.2 (2004): 621-52.

13 Francesca Polletta and James M.Jasper, “Collective Identity and Social Movements," Annual Review in Sociology 27 (2001): 283-305.

14 James M. Jasper, "A Strategic Approach to Collective Action: Looking for Agency in Social Movement Choices," Mobilization 9.1 (2004): 4. 
or progressive-appearing such political parties. These alliances allow CSOs to lobby for their interests with varying degree of success. At this point, the incremental change interaction mode can be discussed. One of the claims I make later in this article is that the current stage of LGBT civil society activism can already be characterized as having shifted to this level and as moving toward the next one. Finally, in the high-profile politics mode, the LGBT community gets full visibility and participates in the public debate as is happening in countries like the UK, the Netherlands, and Sweden.

TABLE 1. STRATEGIES OF CIVIL SOCIETY ORGANIZATIONS BASED ON MODE OF INTERACTION WITH THEIR POLITICAL ENVIRONMENT ${ }^{17}$

\begin{tabular}{llll}
$\begin{array}{l}\text { MODES OF } \\
\text { INTERACTION } \\
\text { STRATEGIES }\end{array}$ & MORALITY POLITICS & $\begin{array}{l}\text { INCREMENTAL } \\
\text { CHANGE }\end{array}$ & $\begin{array}{l}\text { HIGH-PROFILE } \\
\text { POLITICS }\end{array}$ \\
\hline 1. Public visibility & Protest & Small-scale events & $\begin{array}{l}\text { Celebratory public } \\
\text { events }\end{array}$ \\
\hline 2. Coalitions & Difficult & Discreet cooperation & Public cooperation and \\
& & & collaboration \\
\hline 3.Government interaction & Confrontational & Discreet lobbying & Close cooperation \\
\hline 4.Transnational activities & Focus on domestic & May input or export & Export ideas and \\
& struggle. May import & ideas and resources & resources \\
& ideas and resources & & \\
\hline
\end{tabular}

Holzhacker argues that LGBT movements primarily choose their modes of interaction based on the degree of public and elite support for equality and on the partisan or religious opposition to the movement. ${ }^{18}$ In other words, a LGBT group will be able to implement strategies on the high-profile politics level only if the social and political environment is already LGBT-friendly enough. But he does not explain when and under what conditions a civil society organization reshapes its strategies or its mode of interaction. Nor does he explain what factors may cause this change. Based on his argument, a possible explanation is that the change in societal attitudes leads to the change in strategy. Yet, as I argue later, different, more nuanced causal mechanisms might be involved.

While I draw here on Holzhacker's scheme for bringing together social movements' strategies and modes of interaction, I think visibility is particularly important for a LGBT civil society organization. Holzhacker and other social movement scholars ${ }^{19}$ insist that increasing visibility (or explicit presence in the public sphere) is a logical goal of LGBT movements since it allows LGBT activists to make their issue political and bring it to the wider audience. If so, the

17 Holzhacker, "National and Transnational Strategies of LGBT Civil Society Organizations," 8.

18 Holzhacker, "National and Transnational Strategies of LGBT Civil Society Organizations," 21.

19 Mai Palmberg, "Emerging Visibility of Gays and Lesbians in Southern Africa," in The Global

Emergence of Gay and Lesbian Politics: National Imprints of a Worldwide Movement, ed. Barry D. Adam, Jan Willem Duyvendak, and André Krouwel (Philadelphia, PA: Temple University Press, 1999): 266-92. 
"visibility strategy" seems to be the key to successfully moving a LGBT movement from morality politics to the high-profile politics level. At the same time, Currier fairly points out that, though pursuing visibility might be an important general strategy for LGBT movements, becoming visible or "coming out" in a hostile and homophobic environment may expose the movement's participants to the threat of homophobic violence. ${ }^{20}$ Chabot and Duyvendak, however, comment that it is actually in the interest of an LGBT community to become visible in a homophobic environment because the more they enter the public sphere, the safer they may engage in political and cultural work. ${ }^{21}$

The answers social movement scholars give to the question of why and when LGBT movements change their strategies are somewhat confusing. This can partially be explained by the direct causal relation that the studies referenced here attribute to the visibility strategy and the extent to which the political environment is homophobic (less political opportunities for LGBT movement) or LGBT-friendly. Yet it can also be that the decisions taken by LGBT movements are not straightforwardly defined by the emerging political opportunities and are instead based on activists' relationship to mobilization, cultural, and political goals. ${ }^{22}$

This article links the emergence of such political opportunities for the LGBT movement in Ukraine and the growing EU presence in Ukraine. Della Porta and Caiani argue that the presence of "European targets and frames" among the public discourses used by local social movements is on the rise, thus creating the potential for "Europeanization from below," which occurs when the process of public policies and political transformations is driven by civil society actors rather than by political elites. ${ }^{23}$ Ayoub talks about the "European mobilization on behalf of LGBT people" because proximity with the EU gives activists additional advantages such as mobility and access to a large number of "social spaces and organizational resources ... bringing together the main actors and empowering them with the resources for transnational activism ... providing the mobilizing structures to engender a process that was not available in the target state." ${ }^{24}$ At the same time, Slootmaekers and Touquet demonstrate that in new EU memberstates such as Poland, Hungary, and Lithuania, which are comparable to Ukraine due to their post-communist legacy and their situation with LGBT rights, there is a clear backlash against LGBT people: either laws to protect sexual minorities exist on paper only or new homophobic

20 Ashley McAllister Currier, "The Visibility of Sexual Minority Movement Organizations in Namibia and South Africa" (PhD diss., University of Pittsburgh, 2007).

21 Sean Chabot and Jan Willem Duyvendak, "Globalization and Transnational Diffusion between Social Movements: Reconceptualizing the Dissemination of the Gandhian Repertoire and the 'Coming Out' Routine," Theory and Society 31 (2007): 697-740.

22 Mary Bernstein, "Celebration and Suppression: The Strategic Uses of Identity by the Lesbian and Gay Movement," American Journal of Sociology 103 (1997): 371.

23 Donatella Della Porta and Manuela Caiani, "Europeanization from below? Social Movements and Europe," Mobilization 12.1 (2007): 1-20.

24 Phillip M. Ayoub, “Cooperative Transnationalism in Contemporary Europe: Europeanization and Political Opportunities for LGBT Mobilization in the European Union," European Political Science Review 5 (2013): 280. 
legislation is introduced. ${ }^{25}$ This backlash, though, could provide the LGBT movements with even more opportunities to advance their activism and find new allies on transnational and national levels.

The present study, therefore, aims to accommodate Holzhacker's interaction mode typology and the theory of bottom-up Europeanization to explain the shifts in the strategies employed by LGBT civil society organizations in post-Euromaidan Ukraine. I argue that while the external conditions like political climate, approximation with the EU, and societal attitudes play an important role choosing an interaction mode, the process of strategically employing a newly formed collective identity can influence a movement's strategic choices as well as affect its outcomes.

\section{LGBT Movement in Post-Soviet Ukraine: Building a Brand-new Civil Society?}

Before turning to the Euromaidan's events and the developments that followed, it is worth focusing on the relatively short history of the organized LGBT community in Ukraine. During the Soviet era, homosexuality in the Soviet Republic of Ukraine was a crime. Ukraine was the first post-Soviet republic to cancel the correspondent article of the Criminal Code in December 1991, three months after Ukraine became an independent state. ${ }^{26}$ However, this did not further advance the rights of sexual minorities. The topic remained out of the public sphere and was almost completely excluded from political and social debate until the early 2000 .

The emergence of the organized LGBT movement and the establishment of registered organizations started in Ukraine in 1996 and were influenced significantly by Western actors. ${ }^{27}$ While an unorganized LGBT movement already existed, it was mostly invisible externally. After perestroika and the fall of the Soviet regime, new bars and clubs where LGBT individuals could meet each other were opened in the Ukraine's largest cities, this hardly could be defined as a political activity. The first attempt to create a human rights organization took place in Luhansk where a local group of activists founded the organization called "Nash Mir" (Our World) to "protect human rights and freedoms with regard to lesbians, gays, bisexuals, and transgender people." ${ }^{28}$ Initially rejected by local authorities as threatening the moral principles of society, the organization was finally registered in 1999 with substantial support from the Netherlands' ambassador. ${ }^{29}$

25 Koen Slootmaeckers and Helen Touquet, "Old habits Die Hard? The Western Balkans and the Europeanization of LGBT Rights," paper presented at the 2oth International Conference of Europeanists (Amsterdam, June 25-27, 2013): 142.

26 Nash Mir, "History," accessed October 12, 2017, http://www.gay.org.ua/en_content.php?type=55484292.

27 Tamara Martsenyuk, "LGBT dvizhenie v Ukraine: 10 let spustia [LGBT Movement in Ukraine: 10 Years after]," Gendernye issledovaniya (2010): 20-21, accessed October 12, 2017, http://www.gender.univer. kharkov.ua/gurnal/20-21/07.pdf.

28 Nash Mir, "History," accessed July 6, 2017, http://www.gay.org.ua/content.php?type=about_.

29 Sviatoslav Sheremet, "Rano ili pozdno otkrytye LGBT vo vlasti poyavyatsya [Earlier or Later We will have Open LGBT People in Power]," interview by Kolia Kamufliazh, Gay Alliance of Ukraine, 
The emergence and visible development of the main LGBT organizations are related to the wave of the campaigns and programs against HIV/AIDS in Ukraine. Two of the biggest Ukrainian organizations, "Gay Alliance Ukraine" and "Fulkrum" (Tochka Opory), were launched in 2009 using funding from international organizations working on HIV/AIDs prevention (ICF "International HIV/AIDS Alliance in Ukraine, AIDS Healthcare Foundation and Elton John AIDS Foundation). Both organizations later added goals such as the promotion of general human rights and freedoms, fighting homophobia, developing the LGBT community, and raising awareness of and empowering civil society.30

Currently, around 40 LGBT organizations are officially registered in Ukraine. ${ }^{31}$ In 2010-2014, their activity was marked by important campaigns on the national and international levels. For example, according to the representatives of the "Nash Mir" organization, the Ukrainian LGBT community lobbied for the support of the Ukrainian government in 2010 by pressuring the Committee of Ministers of the Council of Europe to adopt the Recommendation on Measures to Combat Discrimination on Grounds of Sexual Orientation or Gender Identity. ${ }^{22}$ Unfortunately, even when the recommendation was translated into Ukrainian, the President of Ukraine and the government ignored its suggestions. Moreover, neither the recommendation nor its translation was published on the government's webpage. In 2012, the government refused to acknowledge a comprehensive "Summary Report on implementation of the Recommendation CM/Rec (2010) 5 of the Committee of Ministers of the Council of Europe on measures to combat discrimination on grounds of sexual orientation or gender identity by Ukraine" produced by "Nash Mir." 33 Previously, the LGBT community had unsuccessfully tried to lobby for the adoption of a bill of the Labor Code that would prohibit employment discrimination based on gender identity and sexual orientation.

To summarize, in Holzhacker's terms the interaction mode the Ukrainian LGBT community could employ before Euromaidan was morality politics because it had extremely low visibility, faced a hostile attitude from the government and political opposition, and was fully dependent on foreign support. As the next section shows, this culminated in 2013 and 2014 with the backlash against LGBT people. This had direct consequences for the strategy the LGBT community chose during Euromaidan.

December 17, 2014, accessed July 6, 2017, http://upogau.org/ru/ourview/ourview_1756.html.

30 See official web-page of “Gay Alliance Ukraine," accessed July 10, 2015, http://upogau.org/ru/about/ info/ and "Fulcrum," accessed July 10, 2015, http://www.t-o.org.ua/work/.

31 LGBT Rada (LGBT Council), accessed October 30, 2017, https://lgbt-rada.org.ua/.

32 Martsenyuk, “LGBT Dvizhenie v Ukraine," 21.

33 Nash Mir, Summary Report on implementation of Recommendation CM/Rec $(2010) 5$ of the Committee of Ministers of the Ministers of the Council of Europe on measures to combat discrimination on grounds of sexual orientation or gender identity by Ukraine, 2012, accessed July 29, 2015, http://www.gay.org.ua/publications/report2o12-e.pdf. 


\section{Ukrainian LGBT Movement and Euromaidan}

The role of LGBT community in the Euromaidan's events has special relevance to the increase in LGBT civil society activism after the Euromaidan. First, although the participation of LGBT community in the protest was almost invisible, it was the first consolidated attempt of local LGBT activists to become a part of a large-scale political action. Beyond that, I argue that the political activism of the LGBT community during the Euromaidan created new opportunities for successful political alliances. Finally, the LGBT community's invisible presence during the Euromaidan is an opening for more discussion about the participation and possible empowerment of other overlooked groups that were active during the Euromaidan. In turn, this raises the question of whether the Euromaidan was indeed such an inclusive and democratic space as it is sometimes portrayed and invites more research into how the Euromaidan affected Ukrainian society.

The mobilization of the Euromaidan protesters occurred through social media networks. Following the news on Facebook, Twitter, and other online sources, LGBT community members almost immediately decided to join the protest at the Maidan Nezalezhnosti, Kyiv's Independence Square. Many of them remained in the protest camp for months, taking an active part in all the Euromaidan activities. Most of the LGBT activists at the Maidan, however, were there as individuals without declaring their affiliation to LGBT community and, in most cases, without making their sexuality an open issue. This reflected the LGBT community's collectively deciding on this approach after its members discussed their Euromaidan participation on an internet forum. The interviewees in several interviews (Interview 2, 3, 5, and 6) revealed that the issue was debated in detail. Because most of the activists agreed that the topic was used by pro-Russian groups to manipulate public opinion, they decided that they would not push the issue of LGBT rights forward so far. The forum brought together members of all the major Ukrainian LGBT organizations and LGBT individuals not affiliated with the formal groups. ${ }^{34}$ Their LGBT activist identity was replaced by the newly born collective identity of a "Euromaidan protester."

The reasons that caused the LGBT protesters to conceal their sexuality can be traced from the politicization of LGBT rights following Ukraine's independence to LGBT rights as an issue in the political discourse about EU accession for Ukraine. The EU's requirement that Ukraine adopt anti-discrimination legislation protecting LGBT people was widely discussed in the months before the Association Agreement had to be signed. One could clearly observe how antiEU integration (and, correspondingly, pro-Russian) discourse was produced. The pro-Russian movement "Ukrainskiy Vybor" (Ukrainian Choice) headed by Viktor Medvedchuk developed a large campaign in summer and fall of 2013 to inform Ukrainians about the negative consequences of association with the EU. The campaign used the conservative homophobic position of a certain segment of the population as an instrument. It spread the myth that the Association Agreement would be oblige Ukraine to recognize same-sex marriages and would "propagate

34 Of course, in the conditions of heavy winter, living among barricades and expecting police to attack any night, it was not the case that anyone in the camp would care about the sexual orientation of the people fighting for the same reasons next to her or him. Nevertheless, it makes sense to discuss the reasons that made LGBT people stay in the shadow and not to display rainbow flags or any other LGBT symbolic. 
homosexuality and LGBT-values." ${ }^{35}$ The organization paid for advertising in some of Ukraine's largest cities that proclaimed: "Ukrainian choice warns: Association Agreement means same-sex marriages" and depicted two men holding hands. The opponents of the approximation with the EU regularly combined homophobic arguments with threats of an economic crisis and growing unemployment "automatically" following the association with the EU. Social media networks were actively used not only by the supporters of Euromaidan, but also by its opponents. ${ }^{36}$

This campaign and the discourse it created was one of the key factors explaining the strategy chosen by Ukrainian LGBT persons during the Euromaidan protests. LGBT organizations published on the website of the All-Ukrainian Public Organization "Gay Alliance Ukraine" an official statement supporting the Association Agreement between the EU and Ukraine. However, they clearly specified that they are not "fighting for specific rights for LGBT" but for a better life for them and their beloved ones in accordance with European standards. ${ }^{37}$ And since certain political groups were speculating on and instrumentalizing the LGBT issue, the community repeatedly announced that it was not planning any action or event covering the problems of sexual minorities because LGBT issues could be abused..$^{38}$ The director of a LGBT organization in Kyiv who was in the protest camp since the first days it existed also noted that

...there were several individuals who preferred to carry a rainbow flag to the camp...I know that some feminists tried doing this, for example. But those who were active in the organized community took part in a [on-line] discussion and the common decision had been made that we come to the camp as Ukrainian citizens supporting European choice of Ukraine. ${ }^{39}$

The LGBT community's concerns proved to be true. During the time when the protest camp was settled in Kyiv, several public actions took place. These actions were later referred to by LGBT activists as prepared by the "Ukrainskii Vybor" to provoke the aggressive reaction of the right-wing participants of the Euromaidan. In January 2014, a group of from 30 to 40 people wearing bright colored clothes, make up, and carrying rainbow flags together with the flags of the EU and of Ukraine arrived in the centre of Kyiv and tried to pitch their own tent at

35 Ukrainskii Vybor, "Ukrainskii Vybor piketiroval predstavitelstvo YeS v Ukraine [Ukrainian Choice Protested in front of the EU Delegation to Ukraine]," October 21, 2013, accessed November 1, 2016, http://vybor.ua/news/Ukrainskii_vybor_piketiroval_predstavitelstvo_es_v_ukraine.html.

36 For example, Internet memes, pictures and articles in various ways bringing together homosexualism, European aspirations of Ukraine and Euromaidan were quite popular among some Internet users. Such publications often employed disdainful reference to Europe as to "Geyropa." Gay Alliance of Ukraine, "Evrorevoluciia v Ukraine: rol i uchastiie LGBT [Eurorevolution in Ukraine: Role and Participation of LGBT]," accessed February 28, 2017, http://upogau.org/ru/ourview/ ourview_59o.html.

38 Gay Alliance of Ukraine, "Zaiavlenie v sviazi s ocherednoi popytkoi ispolzovaniia LGBT dlia diskreditatsii Evromaidana [Declaration Related to One More Attempt to Use LGBT to Discredit Euromaidan)," accessed February 28, 2017, http://upogau.org/ru/inform/uanews/uanews_638.html. 
the Maidan. According to the LGBT activists I interviewed, these people were recruited through social media networks and online forums and promised a specific payment (Interviews 1 and 4). The aim was to make more conservative groups at the Maidan flare up and split the protesters. ${ }^{40}$ The "Council of LGBT organizations of Ukraine" took preventive measures and informed the security and the headquarters of the Maidan protest camp about the possible "provocations." The participants of the camp, therefore, were duly prepared: there was no aggression shown during the performance even from the side of the most radical right-wing groups. This is how one of the activists described the situation in a personal communication:

Couple of our guys went to talk to the right-wing people and explained them the situation, that a provocation is expected ... when these actors came, it was already clear that these were not [real] LGBT people so they could not provoke right-wing groups into a fight.

Author: Did the right-wing groups know that there were LGBT activists in the camp?

— We kind of had "don't ask, don't tell" policy with them. And then, it was so cold, you know, minus 10, and you are afraid of being killed, nobody really cares about your sexuality, we all had a common goal. ${ }^{41}$

The "show" was followed by a press conference at the Ukrainian Independent Information Agency where the activists stressed that the protesters at the Maidan were ignoring the needs of the LGBT community and that their campaign aimed to prove that the Ukrainian LGBT community was actively supporting EU integration. All this was delivered in a carnival-like way and had certain resonance in the media, particularly in Russia. The LGBT community in Ukraine reacted to this with an official statement on TV and social media, declaring that the event was a paid provocation aimed to establish a negative image of LGBT people in the country and their association with the EU and with the protests at the Maidan (National LGBT-portal of Ukraine 2014). Moreover, the group stressed that even though many LGBT people took part in the 20132014 protests at the Maidan, the community jointly and strategically decided not to use LGBT symbols and not to show their affiliation with the LGBT organizations.

In line with Bernstein's argument, the LGBT activists at the Euromaidan prioritized the common political goals of the Euromaidan protesters over their own goal - recognition of the human rights of LGBT people. ${ }^{42}$ They did it to diminish the argument against the Euromaidan as an immoral place and to draw homosexuality away from the European aspirations of Ukraine. As a representative of the "Gay Alliance Ukraine" commented, ${ }^{43}$ staying "invisible" during the protest was a conscious choice of LGBT people as a strategy against existing anti-EU discourse

40 This statement of LGBT activists is supported by the copies of screen-shots of social media networks posts.

41 Interview 4, August 23, 2014, Kyiv.

42 Bernstein, "Celebration and Suppression," 371.

43 Interview 4, August 20, Kyiv. 
(it was also a matter of personal safety due to the homophobic aggressive attitudes of right-wing groups, though). At the same time, the goal of the Euromaidan - to overthrow the government and to join the Association with the EU-did not contradict the long-term objectives of the LGBT community. Most of them expected the EU to actively promote LGBT rights in Ukraine. The decision to stay invisible, therefore, must be addressed from both the collective identity and long-term political strategy perspectives.

The issue of LGBT rights was still in the sphere of morality politics and discreet interactions as the Euromaidan events evolved. They prepared, however, a foundation for the subsequent changes and transformations I will discuss in the next section.

\section{Political “Coming out”: Transforming Post-Euromaidan Political Strategy}

As the protest events in Kyiv were ending, Ukrainian LGBT activists considered the Euromaidan and the slow societal changes accompanied by the increased attention of the EU as a chance to peddle their own interests. The escalated conflict between so-called "the Russian world" (Russkii Mir) and European values gave them hope for achieving more understanding and acceptance among at least those Ukrainians who were the most active during the Euromaidan protests. However, the activists confronted more disappointment when, in 2014, the conflict with Russia turned into a war in Ukraine's Donbas region and a new argument for silencing LGBT issues emerged: "it's not a good time for LGBT rights." In 2014 Vitalii Klychko, the mayor of Kyiv, banned the Equality March claiming that while there was a war in the Eastern Ukraine, it was not a good time for public events that are perceived in as sharply different ways in the society as LGBT rights are. ${ }^{44}$ LGBT community members were disappointed by the ban. A human rights activist described their reaction as follows:

They said that our society was not ready and that it would be an insult to have an "entertaining event" in Kyiv when we have war in the East. Well, to start with it had nothing to do with entertainment. It was about human rights. But then again, we had all these concerts, and TV shows that were indeed inappropriate for the war times and nobody cared! 45

Such behavior from the key political actors could be nothing but discouraging for LGBT activists who expected more support from pro-EU politicians. Lavryk quotes the activists' reaction, mentioning that though the support of the LGBT community as an active human resource was important during the Euromaidan and the protesters seemed to become more accepting and tolerant facing the "common enemy," the situation changed radically after the protests were over.

44 Gay Alliance of Ukraine, "Mer Kieva Vitalii Klichko prizval ne provodit 'Marsh Ravenstva' za prava LGBT (The Mayor of Kyiv Vitalii Klychko Called for Not Organizing 'Equality march' for LGBT Rights)," accessed February 28, 2017, http://upogau.org/ru/inform/uanews/uanews_2316.html. 
The discourse "we'd better have European gays than Putin's faggots" was replaced by "we have a war here and these perverts want to make a parade." 46

By using the European argument after the Euromaidan, the Ukrainian LGBT community ended up between a rock and a hard place. On the one hand, bringing up LGBT rights was problematic because it could be used in Russian propaganda. On the other hand, the rightwing nationalists had an ally against the LGBT community: Russians. They took an extremely conservative position and claimed that "European norms" contradicted Ukrainian traditions and religion and insulted family values. Attributing to the EU the intention to destroy the moral values of Ukrainians and enforce same-sex marriage to Ukrainian society, the local nationalist party "Svoboda" ironically used rhetoric that aligned with the arguments of pro-Russian political forces in Ukraine.

The post-Euromaidan political environment, therefore, proved to be not as tolerant and LGBT-friendly as LGBT activists in the protest camp had hoped. This was reflected in interviews I conducted in the summer of 2015. One of the activists, an openly gay man, referred to a right-wing politician's Facebook post showing this activist wearing a vyshyvanka, a traditional Ukrainian shirt, and the politician's comments that the Euromaidan was not intended to let openly gay people to wear Ukrainian clothes:

He wrote something like "we were not at Maidan to have those faggots wearing our national symbols. Let them all go to ATO [Anti-terroristoperation is a term used to refer to the security operation to deal with the armed conflict in eastern Ukraine]." ${ }^{47}$

Nevertheless, the ongoing conflict with Russia left Ukraine's government dependent on EU support, and this seemed to offer an opportunity for political action to the LGBT community. At the same time, the success of Euromaidan protests and the activists' role in the camp pushed them to use this momentum instead of advancing the "European argument" and using the EU's requirements as reference point to claim LGBT rights. As an example of how the European argument could be used, Bogdan Globa said this at the session of the parliamentary Committee on Human Rights, National Minorities and Interethnic Relations:

We fight discrimination on the ground of sexual orientation ... and I would like to ask my colleagues not to wait with this document [comprehensive anti-discrimination law including sexual orientation and gender identity as the ground for discrimination-M.S.] ...Ukraine took a lot of responsibilities by signing international laws and standards and they already contain all this [provisions on protecting sexual minorities-M.S.]. We do not have to

46 Denys Lavryk, "Gomofobiia V Ukraini: tendentsii postmaidannoho periodu [Homophobia in Ukraine: Post-Maidan Trends]," Commons: Journal of Social Criticism, May 18, 2015, accessed December 21, 2017, http://commons.com.ua/gomofobiya-v-ukrayini/. 
invent a wheel... These strategies are created by the European Union and suggested and recommended to us in our Association Agreement. ${ }^{48}$

Sviatoslav Sheremet, an openly gay activist and the co-coordinator of the national coalition against discrimination, also used the European argument in his open declaration supporting the Equality March and the Pride Week in June 2015 in Kyiv. Sheremet essentially said that Ukraine cannot become a part of united Europe while Ukrainian values are different from Europeans:

I humbly suggest to my friends and enemies to understand: European integration is impossible in principle without guaranteeing human rights and freedoms for LGBT. If you did not want such European integration, why did you make revolution at Maidan? ... This is the question of good judgment and choice: on the one hand, equality for LGBT, on the other hand, life style as they had in Middle Asia. ${ }^{49}$ [italics mine]

The years 2015-2016 witnessed the increasing political participation of LGBT activists and their greater visibility in Ukrainian public sphere. One important development in the Ukrainian political system after the Euromaidan was the appearance of new political actors, who either emerged among the protesters at the Maidan or were moderately active and not that salient in the public sphere before but gained popular support due to the assistance they provided to the protesters. Ukrainian LGBT activists chose the members of these political parties as the targets for lobbying their interests. The tactic of emphasizing the fact that LGBT rights belong to the list of "European values" and are a prerequisite for turning Ukraine into a "European country" started paying dividends in June 2015, when two members of the parliament openly supported LGBT rights. One of them, Svitlana Zalishchuk, even appeared in media-campaign photos with the slogan "It's always time for human rights" to support LGBT pride..$^{50}$ Furthermore, while the Pride Parade in Kyiv in 2015 gathered no more than 220 people, activists referred to the event as an important milestone for the Ukrainian LGBT movement. For the first time in the history of an independent Ukraine, three MPs joined a march for the equality of sexual minorities. Moreover, Ukrainian President Petro Poroshenko, the leading figure in the party in which the MPs joining the parade belonged, expressed his solidarity with the participants by saying: "I will not

48 Ukrlife.TV, "Session of Verkhovna Rada Committee on Human Rights, National Minorities and Inter-ethnic Relations," December 11, 2015, accessed December 21, 2017, https://www.youtube.com/ watch?v=dkjLTm28pPQ.

Sviatoslav Sheremet, “Skazali 'A' — nado govorit 'B': posle Evrorevolutsionirovaniia nado Evroprogressirovat [You have Said 'A', You have to Say 'B': after Eurorevolution should Come Europrogress]," Blogs.Korrespondent.Net, June 3, 2015, accessed February 28, 2016, http://blogs. korrespondent.net/blog/politics/3522701/.

$5^{\circ} \quad$ National LGBT-portal of Ukraine, "Svitlana Zalishchuk pidtrymala provedennya u Kyievi gay-praidu) [Svitlana Zalishchuk Supported Gay Pride in Kyiv]," 2015, accessed February 27, 2017, https://lgbt.org. ua/news/show_2853/. 
participate in it [the Equality March], but I do not see any reason to impede this march because it is a constitutional right of every citizen of Ukraine." 51

In the late 2015, the LGBT community had their first real chance to lobby for legal changes in their favor. As a part of its visa liberalization negotiations with the EU, Ukraine had to adjust its legislation in accordance with the EU Employment Directive. By April 2015, Ulrike Lunacek, an MP from the European Parliament, declared during her visit to Kyiv that no visa facilitation agreement would be signed until Ukraine adopts a law protecting LGBT individuals from discrimination at work.

The first two attempts to pass the amendment failed. On November 1oth, 2015, the LGBT community demonstrated in front of the parliament building, demanding the adoption of antidiscrimination legislation that would include protection for sexual minorities. Some community members were allowed into the parliament's hall. They brought large posters and banners in the support of the bill. It took two more days and additional pressure from the President and his party to pass the legislation on November 12, with 234 votes of 45 o.

Moreover, in November 2015, pressure from civil society groups and the EU resulted in the ordinance by the Cabinet of Ministers of Ukraine "About the confirmation of the action plan for realization of National strategy in the sphere of human rights for the period till 2020." The ordinance, among the other provisions, includes a provision that suggests that the Parliament has until the second quarter of 2017 to draft legislation about the legalization of civil partnerships for heterosexual and homosexual couples. 52

This was followed by the adoption of an amendment to the new part of the plan for implementing the National Strategy in the sphere of human rights for the period until 2020 in February 2016. The Strategy contained a clause about preventing and combating discrimination, including prohibiting discrimination on the grounds of sexual orientation and gender identity. ${ }^{53}$

These changes, including the growing cooperation between the LGBT community and political parties, the lobbying for LGBT rights in the parliament and in national committees, and the increased media visibility signal a shift in the interaction mode of the LGBT community with political authorities from morality politics to incremental change. The LGBT community also became more organized. By the end of 2016, meetings were held to discuss plans to create a National Platform that would include representatives of key, self-organized groups (LGBT individuals, sex workers, people who use drugs), initiative groups, and individual members of communities who want to take part in its work. While these plans have not yet been implemented, individuals I interviewed mentioned the high symbolic meaning all of this has for the community:

$5^{1} \quad$ Christopher Miller, "Ukraine's President Voices LGBT Support in a First for the Country," Mashable. com, June 5, 2015, accessed on February 28, 2017, http://mashable.com/2015/o6/o5/ukrainesporoshenko-supports-pride-parade-in-kiev/\#TMzlM479XZq3. Cabinet of Ministers of Ukraine, Appendix to the Ordinance of the Cabinet of Ministers of Ukraine as of 23.11.2015 no 1393-p. Plan of the Measures for Implementation of National Strategy in the Sphere of Human Rights in the Period Till 2O2O, November 23, 2015, accessed February 28, 2017, http://www. kmu.gov.ua/control/uk/cardnpd?docid=248740679. 
There will be the new Labor Code introduced, for example, and now some MPs are trying to push it through and this law does not contain any mentioning of SOGI even [sexual orientation and gender identity]. We hope, though, that if they [government] will try to cheat on the EU and adopt such a law, the EU will put pressure on them... The most important it, in any case, that words "sexual orientation and gender identity" or "LGBT rights" are pronounced by our leaders and not anymore in negative context exclusively. ${ }^{4}$

Finally, Ukrainian LGBT activists also increased their international visibility, investing substantial effort into strengthening transnational ties and cooperation while stressing the centrality of Ukraine's recognizing LGBT rights in its cooperation with the EU. In March 2016, for example, representatives of Ukrainian LGBT organizations visited the Netherlands to inform the local population about human rights in Ukraine and about the importance of the Dutch consultative referendum on the EU-Ukraine Association that was held a month later. Activists have strong relations with LGBT organizations in Germany and the UK and regularly participate in the annual conference of ILGA Europe.

I have discussed above, though briefly, the changing ways in which political activism of LGBT community was occurring in Ukraine, starting from unorganized interactions and transforming into a part of a protest movement and institutionalized civil society. In the concluding part of this article, I will focus more in detail on placing the key transformations into the framework of Holzhacker's modes of interaction with the political environment, to see how a change of the strategy leads to the change of the political mode of interaction of a social movement.

\section{Discussion: Changing National Strategies for Political Action in Transformed Political Environment}

As I suggested in this article's theoretical sections and have been noting throughout it, the observed transformations fit nicely into the framework suggested by Ronald Holzhacker. I present them again in Table 2.

As it can be seen in the second column and as it was discussed in the corresponding section, before and during the Euromaidan events, LGBT rights were in the area of so-called morality politics. This is when the LGBT community kept a low profile because creating political coalitions was impossible (to accept that homosexuality is normal was considered "political suicide") and material and technical support came only from the Western donors. This explains the communities' almost invisible and confrontational relations with the government. A distinction must be drawn between the low-profile/low visibility position of LGBT community in highly homophobic environment in Ukraine before 2013 and the strategic choices made by the activists during the Euromaidan protests. The analysis of the role of the LGBT activists in the camp offers two valuable insights into Ukrainian civil society activism development. First, it reflects the creation of a new collective identity in the camp with common goals (EU integration, change 
of the government) that LGBT activists prioritized over the movement's goals. The identity argument can be supported by quotes from the interviews (interview 2, quoted earlier, as well as similar references from interviews 4, 5, 6, 31 and 32). These interviewees stressed that they are "Ukrainians with pro-European political stand," first, and a "gay," for example, second or lower.

Second, it explains the nature of the shift in the mode of interaction of the LGBT community with the new government after the Euromaidan, a shift toward incremental change and even, in some respects, toward high-profile politics.

TABLE 2. STRATEGIES AND INTERACTION MODES OF UKRAINIAN LGBT CIVIL SOCIETY ORGANIZATIONS BEFORE AND AFTER THE EUROMAIDAN

\begin{tabular}{|c|c|c|c|}
\hline & BEFORE AND DURING & AFTER EUROMAIDAN, & 2016-2017 FIRST STEPS \\
\hline INTERACTION & EUROMAIDAN/ & 2015/INCREMENTAL & TO HIGH-PROFILE \\
\hline MODES STRATEGIES & MORALITY POLITICS & CHANGE & POLITICS? \\
\hline \multirow[t]{2}{*}{ 1. Public visibility } & Small-scale protest or & \multirow[t]{2}{*}{ Low profile } & Small-scale public (Pride \\
\hline & none & & Parade) and discreet events \\
\hline 2. Coalitions & None & $\begin{array}{l}\text { Attempts of discreet } \\
\text { cooperation }\end{array}$ & Public cooperation \\
\hline \multirow{3}{*}{$\begin{array}{l}\text { 3.Government } \\
\text { interaction }\end{array}$} & Confrontational, openly & \multirow[t]{3}{*}{ Discreet lobbying } & Open demands using \\
\hline & homophobic & & foreign resources and EU \\
\hline & & & leverage \\
\hline \multirow{3}{*}{$\begin{array}{l}\text { 4.Transnational } \\
\text { activities }\end{array}$} & Unsustainable, & \multirow{3}{*}{$\begin{array}{l}\text { Domestic struggle with } \\
\text { reshaped collective } \\
\text { identity }\end{array}$} & Transnational activism, yet \\
\hline & depending on foreign & & still focused on domestic \\
\hline & support organizations & & struggle \\
\hline
\end{tabular}

Source: own study

The post-Euromaidan political environment made the LGBT community face a twofold situation. On the one hand, recognition of LGBT rights was supported and promoted by the $\mathrm{EU}$, and the newly elected government positioned itself as very pro-European (it also needed support from the EU in war with Russia). This created a window for political opportunity for LGBT activists giving them opportunities to lobby for their rights and to build alliances with newly emerged political actors. At the same time, this collaboration had to remain barely visible for quite some time due to the homophobic counter-discourses put forward, first, by the pro-Russian political forces and, later, by the right-wing nationalists. The hope for the change coming with the political transformations was accompanied by the reshaping of the collective identity of the Ukrainian LGBT movement. In the protest camp they presented themselves as Ukrainian citizens supporting European integration without stressing their sexual orientation (e. g. interview 2, 4, 5 and 6). The goals of the movement were in a way postponed for the sake of the greater purpose of association with the EU, which was supposed to bring the desired change for Ukrainian LGBT community, too.

Though the Euromaidan's outcomes might have seem disappointing for LGBT community and, in 2014, resulted in a backlash against LGBT rights in Ukraine, the activists reconsidered 
their political strategy and managed to use their movement's momentum, shifting first towards the incremental change and later even to the high profile politics interaction mode. This could be seen from growing presence of LGBT activists in Ukrainian state institutions, including parliamentary committees; public interaction between LGBT activists and Ukrainian politicians; and public demands by LGBT activists for legal changes using the EU as the reference point.

Persisting homophobia in the Ukrainian public sphere and the slow implementation of the legal changes introduced in $2015^{-2016}$ does not suggest that Ukrainian LGBT civil society has already shifted towards what Holzhacker defines as "high-profile politics interaction." He uses this term to refer to the situation in countries like the Netherlands, where the Pride Parade is openly celebrated, and LGBT people enjoy public visibility and equal civic rights. One can spot, though, the first steps that the LGBT movement in Ukraine is taking toward this interaction mode. Among those are the growing involvement of Ukrainian LGBT activists in transnational activism and their regular participation in international LGBT conferences and forums increasing the presence and representation of Ukrainian LGBT movement across the world. For example, in October 2016, Olena Shevchenko, one of the most prominent Ukrainian LGBT activists, was elected a member of the board of ILGA-Europe, the European Region of the International Lesbian, Gay, Bisexual, Trans and Intersex Association. The ILGA is an international non-governmental umbrella organization bringing together 490 organizations from 45 European countries. The Equality March safely and successfully took place in the centre of Kyiv in 2016 and 2017 with the participation of several MPs. The representatives of major LGBT organizations have been included on parliamentary committees, have spoken in the Parliament, and have become more visible on the national TV and in social media. As this article shows, this became possible due to the growing presence of the EU in the country and the efforts of the civil society using their Euromaidan momentum and employing "European frames and arguments" in their struggles. Still, one must refer to highprofile politics for Ukrainian LGBT activism with significant reservations, as the scale of the public events remains rather small and the visibility of those is limited because of potential violent attacks on the activists from the side of homophobic groups. ${ }^{55}$

This article's purpose was to analyze the changes in the strategies of Ukrainian LGBT movement from the 199os until the present and identify the factors that caused the shifts in its political actions. The article applied the interaction framework suggested by Holzhacker to the analysis of developing civil society activism in sphere of LGBT rights. While the framework seems to fit nicely to reflect the dynamics of the movement evolution in last several years, to grasp the nature of the shifts from one interaction mode to another, this article suggests analyzing complex interrelation of both domestic and external factors influencing the movement. Among such factors, the instrumentalization of LGBT issues by pro-Russian groups, the geopolitical conflict Ukraine was involved in, and the further growing approximation with the EU have been important. The events of the Euromaidan were among the factors that triggered transformations within the Ukrainian LGBT community and created room for the change of the political strategies and of the

55 The annual reports presented by Nash Mir (available in English at http://gay.org.ua/en/blog/ category/situation-of-lgbt-in-ukraine/) regularly highlight persisting attacks by the representatives of right-wing organizations as well as unidentified hooligans on LGBT-related events both in Kyiv and in other major cities of Ukraine where such events take place. 
political mode of interaction of LGBT movement in Ukrainian public sphere. The complicated geopolitical situation in which Ukraine found itself after the Euromaidan and the domestic political conflict between pro-EU and right-wing nationalist forces led to a backlash against LGBT rights in the country. During this backlash, not only was the topic of the legal change silenced, but also more and more homophobic rhetoric sounded in the domestic public discourses. Yet such a turn created a subsequent feeling of disillusion among the LGBT community, which triggered a new wave of LGBT activism resulting in improved, more effective political strategies. With the growing popularity of pro-European integration attitudes in the country, the LGBT organizations used the EU human rights requirements as an argument and a starting point to lobby their political interests and to build new coalitions. Having further employed new strategies of political activism, namely, media appearances, increased visibility during political events transnational networking, alliances with pro-European politicians, civil society LGBT organizations in Ukraine is now slowly moving towards the next level of the interaction mode that Holzhacker defines as "higher politics."

It is undeniable that the pace of changes for sexual minorities in Ukraine remains slow. Yet one should not forget that only three years ago, the baseless allegation that the EU might demand that Ukraine allow same-sex marriages was presented as a "legitimate" reason not to sign an association agreement with the EU, and supporting publicly LGBT rights was defined as "political suicide." In 2016, not only have the first MPs openly spoken in favor of LGBT rights and marched with LGBT activists, but also the president of the country supported equal rights of LGBT people despite the homophobic attitudes of the population. In other words, the new strategies employed by Ukrainian LGBT civil society activists were chosen to align with current domestic and international political developments, and they seem to have borne tangible results.

One can question, however, how stable these results are. The short time in which the legal and political changes have taken place was not enough for larger scale change of attitudes across the Ukrainian society. The latter would require a transformation of education system, more awareness rising public events, and other long-term measures. While, for now, it is possible to speak of a shift of Ukraine's society toward a more open and inclusive one, it remains to be seen whether the positive dynamics will persist.

\section{Bibliography}

Ayoub, Phillip M. "Cooperative Transnationalism in Contemporary Europe: Europeanization and Political Opportunities for LGBT Mobilization in the European Union." European Political Science Review 5 (2013): 279-310.

Bernstein, Mary. "Celebration and Suppression: The Strategic Uses of Identity by the Lesbian and Gay Movement." American Journal of Sociology 103 (1997): 531-65.

Cabinet of Ministers of Ukraine. Appendix to the Ordinance of the Cabinet of Ministers of Ukraine as of 23.11.2015 no 1393-p. Plan of the measures for realization of National Strategy in the sphere of human rights in the period till 2020. (2015, November 23). Accessed February 28, 2017. http://www.kmu.gov.ua/control/uk/cardnpd?docid=248740679. 
Cabinet of Ministers of Ukraine. Appendix to the Ordinance of the Cabinet of Ministers of Ukraine as of 16.02.2016 no 2/o2-16. Plan of the Measures for Realization of National Strategy in the Sphere of Human Rights in the Period till 2020 (2016, February).

Chabot, Sean, and Jan Willem Duyvendak. "Globalization and Transnational Diffusion between Social Movements: Reconceptualizing the Dissemination of the Gandhian Repertoire and the 'Coming Out' Routine." Theory and Society 31 (2002): 697-740.

Currier, Ashley McAllister. "The Visibility of Sexual Minority Movement Organizations in Namibia and South Africa." (PhD diss., University of Pittsburgh, 2007).

Della Porta, Donatella, and Manuela Caiani. "Europeanization from Below? Social Movements and Europe." Mobilization 12.1 (2007): 1-20.

Della Porta, Donatella, and Mario Diani. Social Movements. An Introduction. Oxford, UK: Blackwell Publishing, 2006.

Edwards, Bob, and John D. McCarthy. "Strategy Matters: The Contingent Value of Social Capital in the Survival of Local Social Movement Organizations." Social Forces 83.2 (2004): 621-52.

Gay Alliance of Ukraine. "Evrorevolutsiia v Ukraine: rol i uchastiie LGBT [Eurorevolution in Ukraine: Role and Participation of LGBT]." July 2013. Accessed February 28, 2017. http:// upogau.org/ru/ourview/ourview_59o.html.

Gay Alliance of Ukraine. "Zaiavlenie v sviazi s ocherednoi popytkoi ispolzovaniia LGBT dlia diskreditatsii Evromaidana [Declaration Related to One More Attempt to Use LGBT to Discredit Euromaidan).” December 2013. Accessed February 28, 2017. http://upogau.org/ ru/inform/uanews/uanews_638.html.

Gay Alliance of Ukraine. "Mer Kieva Vitalii Klichko prizval ne provodit 'Marsh Ravenstva' za prava LGBT [The Mayor of Kyiv Vitalii Klychko Called for not Organizing 'Equality March' for LGBT Rights]." June 2014. Accessed February 28, 2017. http://upogau.org/ru/inform/ uanews/uanews_2316.html.

Holzhacker, Ronald L. "National and Transnational Strategies of LGBT Civil Society Organizations in Different Political Environments: Modes of Interaction in Western and Eastern Europe for Equality." Comparative European Politics 10 (2010): 1-25.

Jasper, James M. The Art of Moral Protest: Culture, Biography, and Creativity in Social Movements. Chicago: University of Chicago Press, 1997.

Jasper, James M. "A Strategic Approach to Collective Action: Looking for Agency in Social Movement Choices." Mobilization 9.1 (2004): 1-16.

Jasper, James M. "From Macro Opportunities to Micro Mechanisms." In Contention in Context, ed. J. Goodwin and J. M. Jasper. Stanford: Stanford University Press, 2012.

Jasper, James M. “¿De la estructura a la acción? La teoría de los movimientos sociales después de los grandes paradigmas." Sociologica 27.75 (2012): 7-48.

Lavryk, Denys. "Gomofobiia v Ukraini: tendentsii postmaidannoho periodu [Homophobia in Ukraine: Post-Maidan Trends]." Commons:Journal of Social Criticism. May 18, 2015. Accessed December 21, 2017. http://commons.com.ua/gomofobiya-v-ukrayini/.

Martsenyuk, Tamara. "LGBT Dvizhenie v Ukraine: 10 let spustia (LGBT Movement in Ukraine: 10 years after)". Gendernye issledovaniya (2010): 20-21. http://www.gender.univer.kharkov. ua/gurnal/20-21/o7.pdf. 
Miller, Christopher. "Ukraine's president voices LGBT support in a first for the country”. Mashable. com. (2015, June 5). Accessed 28 February 2017. http://mashable.com/2015/o6/o5/ukrainesporoshenko-supports-pride-parade-in-kiev/\#TMzlM479XZq3.

Nash Mir. Summary Report on implementation of Recommendation CM/Rec(2010)5 of the Committee of Ministers of the Ministers of the Council of Europe on measures to combat discrimination on grounds of sexual orientation or gender identity by Ukraine. (2012) http://www.gay.org.ua/publications/report2012-e.pdf.

Nash Mir. 2014. History. Accessed November 1, 2017. http://www.gay.org.ua/en_content. php?type $=55484292$.

National LGBT-portal of Ukraine. "Svitlana Zalishchuk pidtrymala provedennya u Kyievi gaypraidu [Svitlana Zalishchuk Supported Gay Pride in Kyiv]." June 2015. Accessed February 27, 2017. https://lgbt.org.ua/news/show_2853/.

Nepstad, Sharon Erickson, and Stellan Vinthagen. "Strategic Choices in Cross-National Movements: A Comparison of the Swedish and British Plowshares Movement." In Strategies for Social Change, edited by Gregory Maney, Rachel Kutz-Flamenbaum, Deana Rohlinger, and Jeff Goodwin, 263-84. Minneapolis: University of Minnesota Press, 2012.

Palmberg, Mai. "Emerging Visibility of Gays and Lesbians in Southern Africa." In The Global Emergence of Gay and Lesbian Politics: National Imprints of a Worldwide Movement, edited by Barry D. Adam, Jan Willem Duyvendak, and André Krouwel, 266-02. Philadelphia, PA: Temple University Press, 1999.

Polletta, Francesca and James M.Jasper. "Collective Identity and Social Movements." Annual Review in Sociology 27 (2001): 283-305.

Rossi, Federiko M. "Conceptualizing Strategy Making in a historical and Collective Perspective". In Social Movements Dynamics. New Perspectives on Theory and Research from Latin America, edited by Rossi, Federiko M. and Marisa von Bülow, 15-42. London and New York: Routledge, 2016.

Sheremet, Sviatoslav. "Rano ili pozdno otkrytyie LGBT vo vlasti poyavyatsya [Earlier or later we will have open LGBT people in power]," interview by Kolia Kamufliazh, Gay Alliance, December 17, 2014. Accessed December 21, 2017. http://upogau.org/ru/ourview/ourview_1756.html.

Sheremet, Sviatoslav. "Skazali "A" — nado govorit' i "B": posle Evrorevolutsionirovniia nado Evroprogressirovat"” (You have said "A", you have to say "B": after Eurorevolution should come Europrogress). Blogs. Korrespondent.Net. June 3, 2015, Accessed December 21, 2017. http://blogs.korrespondent.net/blog/politics/3522701/.

Shevchenko, Inna. “Kyiv Pride 2016: Why are Ukraine's Politicians Silent on Attacks against LGBT People?" International Business Times. June 11, 2016, Accessed December 21, 2017 http:// www.ibtimes.co.uk/kiev-pride-2016-why-are-ukraines-politicians-silent-attacks-againstlgbt-people-156483o.

Slootmaeckers, Koen, and Helen Touquet. "Old Habits Die Hard? The Western Balkans and the Europeanization of LGBT Rights'. Paper presented at the 2oth International Conference of Europeanists (Amsterdam, June 25-27, 2013).

Smithey, Lee A. "Social Movement Strategy, Tactics, and Collective Identity." Sociology Compass 3.4 (2009): 658-71. 
Tarrow, Sidney. Power in Movement. Social Movements and Contentious Politics. Cambridge: Cambridge University Press, 1994.

Taylor, Verta, and Nella Van Dyke. "Get up, Stand up": Tactical Repertoires of Social Movements." In The Blackwell Companion to Social Movement, edited by Snow, David A., Sarah A. Soule, and Hanspeter Kriesi, 262-93. Malden, Oxford, Carlton: Blackwell Publishing Ltd, 2004.

Ukrainskii Vybor. "Ukrainskii Vybor piketiroval predstavitelstvo YeS v Ukraine [Ukrainian Choice Protested against EU Delegation to Ukraine]." October 21, 2013. http://vybor.ua/news/ ukrainskiy_vybor_piketiroval_predstavitelstvo_es_v_ukraine.html.

Ukrlife.TV. "Session of Verkhovna Rada Committee on Human Rights, National Minorities and Interethnic Relations." December 11, 2015. Accessed December 21, 2017. https://www. youtube.com/watch?v=dkjLTm28pPQ.

Williams, Matthias, and Natalia Zinets. "Prize from West after mostly Peaceful Kyiv Pride March." Reuters, June 12, 2016. Accessed December 21, 2017. http://www.reuters.com/article/usukraine-pride-parade-idUSKCN oYY oFD.

\section{(7)}

Maryna Shevtsova holds $\mathrm{PhD}$ in Political science from the Humboldt University, Berlin. Her doctoral thesis analyzes the processes of Europeanization and promotion of LGBT rights as "European" norms in the EU Neighborhood. She also holds PhD in Economics from Dnepropetrovsk National University, Dnipro, Ukraine and MA in Gender studies from Central European University, Budapest, Hungary. Maryna Shevtsova is an associate at Ukraine Democracy Initiative and Senior Adjunct Fellow at the Institute for Euro-Atlantic Cooperation (IEAC), Kyiv, Ukraine. Since November 2017, she works as Project Manager at TERGO, LGBT parents' initiative.

\section{Appendix 1: List of the Interviews (ordered chronologically) ${ }^{56}$}

\begin{tabular}{llll} 
& \multicolumn{3}{c}{ NAME AND POSITION OF } \\
NO & ORGANIZATION & PERSON(s) INTERVIEWED & DATE AND LOCATION \\
\hline Interview 1 & $\begin{array}{l}\text { NGO dealing with human } \\
\text { rights and democratization } \\
\text { issues, Kyiv office }\end{array}$ & Program coordinator & August 21, 2014 \\
& & & \\
\hline Interview 2 & Ukrainian LGBT CSO \# 1 & Director & $\begin{array}{l}\text { August 22, 2014 } \\
\text { Kyiv, Ukraine }\end{array}$ \\
\hline
\end{tabular}

$5^{6} \quad$ For the purpose of keeping confidentiality, most of the interviews are anonymized. 
The ups and downs of LGBT Activism in the Ukrainian Public Sphere

\begin{tabular}{|c|c|c|c|}
\hline Interview 3 & Ukrainian LGBT CSO \#2 & $\begin{array}{l}\text { Director } \\
\text { Project Manager } \\
\text { LGBT activist, former volunteer } \\
\text { of the organization }\end{array}$ & $\begin{array}{l}\text { August 23, } 2014 \\
\text { Kyiv, Ukraine }\end{array}$ \\
\hline Interview 4 & & $\begin{array}{l}\text { August 23,2014 } \\
\text { Kyiv, Ukraine }\end{array}$ & \\
\hline Interview 5 & & $\begin{array}{l}\text { August 24, } 014 \\
\text { Kyiv, Ukraine }\end{array}$ & \\
\hline $\begin{array}{l}\text { Interview } 6,7 \\
\text { (together) }\end{array}$ & & $\begin{array}{l}\text { LGBT activists, members of the } \\
\text { organization committee of Kyiv } \\
\text { Pride Week in } 2014 \text { and } 2015\end{array}$ & $\begin{array}{l}\text { August 25, } 2014 \\
\text { Kyiv, Ukraine }\end{array}$ \\
\hline Interview 8 & & $\begin{array}{l}\text { LGBT activist, expert at UNDP } \\
\text { program }\end{array}$ & $\begin{array}{l}\text { August 25, } 2014 \\
\text { Kyiv, Ukraine }\end{array}$ \\
\hline \multicolumn{4}{|c|}{ BRUSSELS, BELGIUM, FEBRUARY 2015} \\
\hline Interview 9 & $\begin{array}{l}\text { European Parliament's } \\
\text { Intergroup on LGBT Rights }\end{array}$ & $\begin{array}{l}\text { Evert Jacobsen, } \\
\text { Secretary }\end{array}$ & $\begin{array}{l}\text { February 6,2015 } \\
\text { Brussels, Belgium }\end{array}$ \\
\hline Interview 10 & ILGA-Europe & $\begin{array}{l}\text { Lilit Poghosyan, } \\
\text { Senior Programs and Policy } \\
\text { Officer }\end{array}$ & $\begin{array}{l}\text { February 10, } 2015 \\
\text { Brussels, Belgium }\end{array}$ \\
\hline Interview 11 & $\begin{array}{l}\text { European Commission } \\
\text { Director-General for Justice } \\
\text { and Consumers } \\
\text { Unit } \mathrm{C}_{1} \text { - Fundamental rights } \\
\text { and rights of the child }\end{array}$ & $\begin{array}{l}\text { Linda Ravo, } \\
\text { Legal and policy officer }\end{array}$ & $\begin{array}{l}\text { February 11, } 2015 \\
\text { Brussels, Belgium }\end{array}$ \\
\hline Interview 12 & $\begin{array}{l}\text { EQUINET_-European Network } \\
\text { of Equality Bodies }\end{array}$ & $\begin{array}{l}\text { Anne Gaspard, } \\
\text { Executive Director }\end{array}$ & $\begin{array}{l}\text { December 12, } 2015 \\
\text { Brussels, Belgium }\end{array}$ \\
\hline & KYIV AND DN & IIPRO, UKRAINE, JUNE 2015 & \\
\hline Interview 13 & $\begin{array}{ll}\text { European Union Delegation } & \mathrm{St} \\
\text { to Ukraine } & \mathrm{Se} \\
\mathrm{H}\end{array}$ & $\begin{array}{l}\text { tanislav Topolnytskii } \\
\text { ector Manager, Civil Society and } \\
\text { uman Rights }\end{array}$ & $\begin{array}{l}\text { June 8, } 2015 \\
\text { Kyiv, Ukraine }\end{array}$ \\
\hline Interview 14 & $\begin{array}{l}\text { European Union Delegation Ju } \\
\text { to Ukraine }\end{array}$ & $\begin{array}{l}\text { lan Manuel Vilaplana Lopez, } \\
\text { dvisor on Political Affairs }\end{array}$ & $\begin{array}{l}\text { June 8, } 2015 \\
\text { Kyiv, Ukraine }\end{array}$ \\
\hline Interview 15 & & tern & $\begin{array}{l}\text { June 9, } 2015 \\
\text { Kyiv, Ukraine }\end{array}$ \\
\hline Interview 16 & Kyiv Pride Forum & $\begin{array}{l}\text { eminist and LGBT movement } \\
\text { ctivist, gender researcher, co- } \\
\text { rganizer }\end{array}$ & $\begin{array}{l}\text { June 10, } 2015 \\
\text { Kyiv, Ukraine }\end{array}$ \\
\hline
\end{tabular}




\begin{tabular}{|c|c|c|c|}
\hline \multirow[t]{2}{*}{ Interview 17} & \multirow{2}{*}{\multicolumn{2}{|c|}{$\begin{array}{l}\text { Assistant to an MP from "Petro } \\
\text { Poroshenko blok", activist }\end{array}$}} & June 10, 2015 \\
\hline & & & Kyiv, Ukraine \\
\hline \multirow[t]{2}{*}{ Interview 18} & \multirow{2}{*}{\multicolumn{2}{|c|}{$\begin{array}{l}\text { Activist, participant of Euromaidan } \\
\text { protests in } 2013^{-2014}\end{array}$}} & June 11, 2015 \\
\hline & & & Kyiv, Ukraine \\
\hline \multirow[t]{2}{*}{ Interview 19} & \multirow{2}{*}{\multicolumn{2}{|c|}{ Activist, lawyer, political expert }} & June 12, 2015 \\
\hline & & & Dnipro, Ukraine \\
\hline \multicolumn{4}{|c|}{ KYIV, MARCH—AUGUST 2016} \\
\hline \multirow{5}{*}{$\begin{array}{l}\text { Interview } 20 \\
\text { Interview } 21\end{array}$} & \multirow{5}{*}{$\begin{array}{l}\text { Kyiv-based LGBT NGO focusing } \\
\text { on transgender people's rights } \\
\text { in Ukraine }\end{array}$} & Project coordinator & March 15, 2016 \\
\hline & & & Kyiv, Ukraine \\
\hline & & & \\
\hline & & Director & March 16, 2016 \\
\hline & & & Kyiv, Ukraine \\
\hline \multirow[t]{2}{*}{ Interview 22} & \multirow[t]{2}{*}{ Human Rights Center } & Expert & March 16, 2016 \\
\hline & & & Kyiv, Ukraine \\
\hline \multirow[t]{2}{*}{ Interview 23} & & Assistant to an MP & March 19, 2016 \\
\hline & & & Kyiv, Ukraine \\
\hline \multirow[t]{2}{*}{ Interview 24} & & Human rights expert & March 19, 2016 \\
\hline & & & Kyiv, Ukraine \\
\hline \multirow[t]{2}{*}{ Interview 25} & & Trans activist & March 19, 2016 \\
\hline & & & Kyiv, Ukraine \\
\hline \multicolumn{4}{|c|}{ FOLLOW-UP INTERVIEWS } \\
\hline \multirow[t]{2}{*}{ Interview 26} & LGBT rights NGO & Director & August 21, 2016 \\
\hline & Project coordinator & & Kyiv, Ukraine \\
\hline \multirow[t]{2}{*}{ Interview 27} & & & August 21, 2016 \\
\hline & & & Kyiv, Ukraine \\
\hline \multirow[t]{2}{*}{ Interview 28} & Human rights and & Project coordinator & August 22, 2016 \\
\hline & democratization NGO & & Kyiv, Ukraine \\
\hline \multirow[t]{2}{*}{ Interview 29} & & LGBT activist, volunteer for Kyiv & August 23, 2016 \\
\hline & & Pride week 2015 and 2016 & Kyiv, Ukraine \\
\hline \multirow[t]{2}{*}{ Interview 30} & & Political scientists, LGBT rights & August 23, 2016 \\
\hline & & expert & Kyiv, Ukraine \\
\hline \multirow[t]{2}{*}{ Interview 31} & & Feminist activist, volunteer to & August 23, 2016 \\
\hline & & LGBT rights organization & Kyiv, Ukraine \\
\hline \multirow[t]{2}{*}{ Interview 32} & LGBT rights organization & Director & August 23, 2016 \\
\hline & & & Kyiv, Ukraine \\
\hline
\end{tabular}

